\section{(6) OPEN ACCESS}

\title{
Copper deficiency caused by excessive alcohol consumption
}

\author{
Shunichi Shibazaki, ${ }^{1}$ Shuhei Uchiyama, ${ }^{2}$ Katsuji Tsuda, $^{3}$ Norihide Taniuchi $^{4}$
}

${ }^{1}$ Department of Emergency and General Internal Medicine, Hitachinaka General Hospital, Hitachinaka, Ibaraki, Japan ²Department of General Internal Medicine, Tokyo Bay Urayasu Ichikawa Medical Center, Urayasu, Chiba, Japan ${ }^{3}$ Department of Nephrology, Suwa Central Hospital, Chino, Nagano, Japan ${ }^{4}$ Department of Gastroenterology and Internal Medicine, Suwa Central Hospital, Chino, Nagano, Japan

Correspondence to Dr Shunichi Shibazaki, sn1.shibazaki@gmail.com

Accepted 12 September 2017

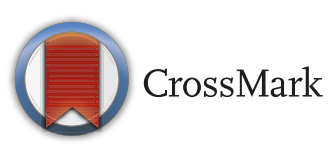

To cite: Shibazaki $S$, Uchiyama S, Tsuda K, et al. BMJ Case Rep Published Online First: [please include Day Month Year]. doi:10.1136/bcr-2017220921

\section{SUMMARY}

Copper deficiency is a disease that causes cytopaenia and neuropathy and can be treated by copper supplementation. Long-term tube feeding, long-term total parenteral nutrition, intestinal resection and ingestion of zinc are known copper deficiency risk factors; however, alcohol abuse is not. In this case, a 71-year-old man had difficulty waking. He had a history of drinking more than five glasses of spirits daily. He was well until 3 months ago. A month before his visit to our hospital, he could not eat meals but continued drinking. He had macrocytic anaemia on admission. Copper and ceruloplasmin levels were markedly low, and we diagnosed copper deficiency. There were no other known risk factors for copper deficiency. After he began drinking cocoa as a copper supplement, the anaemia ameliorated and he was able to walk. This is the first report showing alcohol abuse as a risk factor for copper deficiency.

\section{BACKGROUND}

Copper deficiency is a disease that causes blood cell abnormalities such as anaemia and leucopaenia ${ }^{1}$, and neurological symptoms such as neuropathy, myelopathy and vision loss. ${ }^{2}$ It needs to be differentiated from vitamin B 12 deficiency. Although the precise frequency is unknown, primary copper deficiency is relatively rare because copper is universally included in the diet. ${ }^{3}$ Therefore, it should be suspected when the patient has a known risk factor. Current known risk factors include special nutritional conditions such as long-term tube feeding ${ }^{4}$ and long-term total parenteral nutrition ${ }^{5}$, gastrointestinal problems such as postgastrectomy ${ }^{6}$ and postobesity surgery ${ }^{7}$ and other conditions, such as ingestion of zinc. ${ }^{8}$ There are also several copper deficiency case reports of unknown causes, ${ }^{9}$, which suggests that there are other risk factors. Currently in the literature, there are no case reports of alcohol abuse as a risk for copper deficiency. We experienced a case of copper deficiency due to alcohol abuse without other known risk factors.

\section{CASE PRESENTATION}

A 71-year-old man was a long-term alcoholic that drank more than five glasses of spirits daily. Beginning 3 months ago, he began to eat less at meals that consisted mostly of raw fish and meat and continued to drink alcohol. However, he had no other problems in daily life. One month ago, he could no longer eat meals but continued drinking. At about this time, he became unable to walk and managed by crawling. A day before his visit to our hospital, his behaviour became unintelligible, and he was brought to our hospital by ambulance. He had a history of hypertension and dyslipidaemia and took amlodipine and rosuvastatin. He has no history of surgery and he did not take zinc medication or supplementation.

Vital signs were the following: blood pressure 96/72 $\mathrm{mm} \mathrm{Hg}$, pulse $89 / \mathrm{min}$, body temperature $36.7^{\circ} \mathrm{C}$, respiration rate $15 / \mathrm{min}$ at time of visit. $\mathrm{He}$ lost consciousness and could not understand where he was or respond to instructions. His ocular conjunctiva was yellow tinged and he had a flapping tremor. He had an abdominal bulge and no knock pain around his liver. He had brown diarrhoea, not tarry stool. He was unable to stand up to both knees. Babinski reflection was positive. He was uncooperative with our physical examination, and as such, a detailed neurological examination including serial exams was not possible.

\section{INVESTIGATIONS}

Blood tests revealed a white blood cell count of $5190 / \mu \mathrm{L}$ without abnormal fractionation. His haemoglobin $(\mathrm{Hb})$ was $7.8 \mathrm{~g} / \mathrm{dL}$ (normal range 13.5-17.6 g/dL), mean corpuscular volume was $107.4 \mathrm{fl}$ (normal range 83-93 fl), reflecting macrocytic anaemia. Platelet count was $11.7 \times 10^{4} / \mu \mathrm{L}$ (normal range $13.1 \times 10^{4}-36.2 \times 10^{4} / \mu \mathrm{L}$ ), reflecting mild thrombocytopaenia. Aspartate aminotransferase was $477 \mathrm{IU} / \mathrm{L}$ (normal range 7-97 IU/L), alanine aminotransferase was 155 IU/L (normal range 6-43 IU/L), blood urea nitrogen was 26.7 $\mathrm{mg} / \mathrm{dL}$ (normal range $10-20 \mathrm{mg} / \mathrm{dL}$ ), creatinine $2.41 \mathrm{mg} / \mathrm{dL}$ (normal range $0.6-1.0 \mathrm{mg} / \mathrm{dL}$ ), that is, liver and kidney dysfunction were also observed. Blood glucose level was normal (137 mg/dL). Ammonia level increased up to $166 \mu \mathrm{g} / \mathrm{dL}$ (normal range $30-80 \mu \mathrm{g} / \mathrm{dL}$ ). His serum ferritin also significantly increased up to $9506 \mathrm{ng} / \mathrm{mL}$ (normal range $39.4-340 \mathrm{ng} / \mathrm{mL}$ ). C-reactive protein was 5.89 $\mathrm{mg} / \mathrm{dL}$ (normal range $0.0-0.3 \mathrm{mg} / \mathrm{dL}$ ). However, urinary white blood cells and bacterial urine were negative, thus excluding pyelonephritis. In addition, ascites had no bacteria, while white blood cell count in ascites was $32 / \mu \mathrm{L}$, thus also excluding spontaneous bacterial peritonitis. The following data are reference values because these blood tests were investigated after vitamin ingestion at the emergency department; serum vitamin B1 $91 \mathrm{ng} /$ $\mathrm{mL}$ (normal range $24-66 \mathrm{ng} / \mathrm{mL}$ ) and serum vitamin B12 > $1500 \mathrm{pg} / \mathrm{mL}$ (normal range $180-914 \mathrm{pg} / \mathrm{mL}$ ). Prothrombin time (PT) was $16.5 \mathrm{~s}$ (normal range 

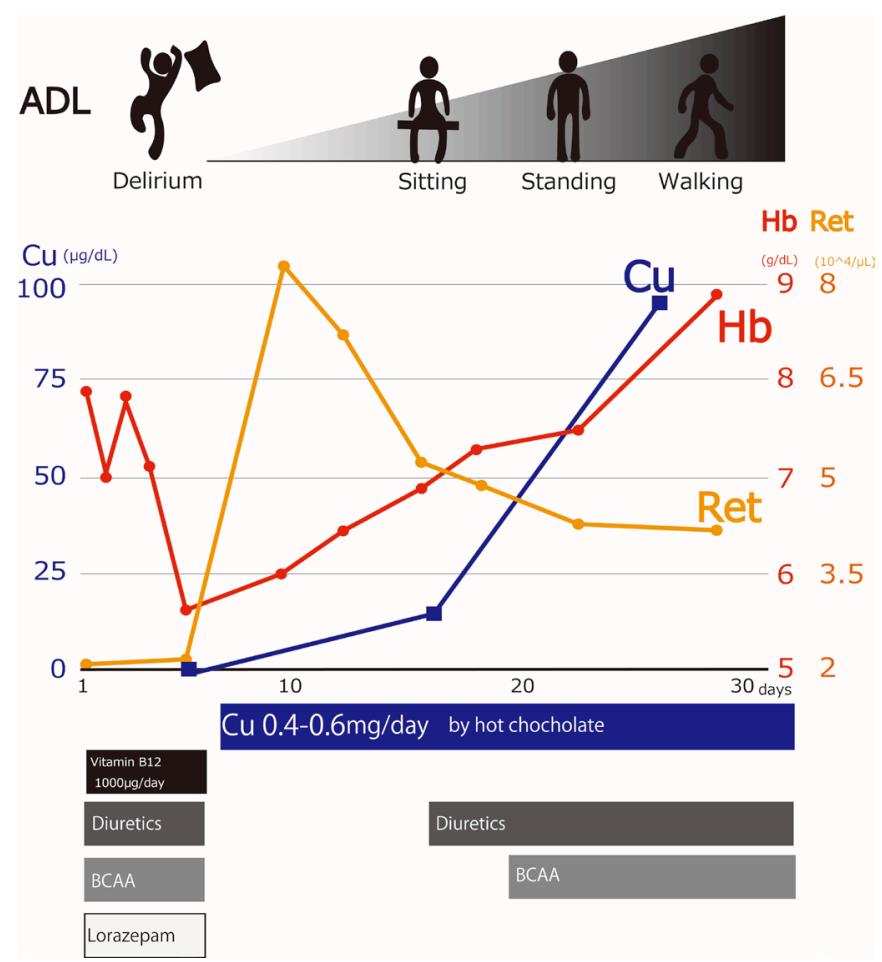

Figure 1 Clinical course of this case. Initially, symptoms did not improve with multiple treatments. However, it improved dramatically with copper supplementation via cocoa. ADL, activity of daily life; BCAA, branched chain amino acid; $\mathrm{Hb}$, haemoglobin; Ret, reticulocyte.

11-14 s), PT\% was 51.9\% (normal range 80-120\%). Head CT revealed no abnormality, however, abdominal CT showed an advanced fatty liver and a massive amount of ascites.

Since he ramped and was uncooperative with our investigation, it was impossible to conduct a detail examination such as with upper gastrointestinal endoscope to rule out gastrointestinal bleeding. MRI of the spine and brain to confirm the cause of being unable to walk was also not possible.

\section{TREATMENT}

Initially, we suspected vitamin B12 deficiency with hepatic encephalopathy and prerenal renal failure. Therefore, intravenous vitamin B12 supplementation (more than $1000 \mu \mathrm{g}$ daily), branched chain amino acid (BCAA) administration and replacement fluid were administered. Lactulose was not used because he was not constipated but rather had diarrhoea. Lorazepam was also administered to prevent alcohol withdrawal. Antibiotics were not used because there was no finding to affirm bacterial infection. In addition, corticosteroid was not used because there were few findings to suggest acute alcoholic hepatitis such as fever, tachycardia and liver knock pain.

These treatments, however, did not recover symptoms, which instead worsened. For that reason, we suspected another disease: copper deficiency mimicking vitamin B12 deficiency. Later on, tests showed that the serum copper level was under $2 \mu \mathrm{g} / \mathrm{dL}$ (normal range 68-128 $\mu \mathrm{g} / \mathrm{dL}$ ), and the serum ceruloplasmin level was $8 \mathrm{mg} / \mathrm{dL}$ (normal range $21-37 \mathrm{mg} / \mathrm{dL}$ ). Therefore, we diagnosed that the main disease was not vitamin B12 deficiency but copper deficiency instead. Additionally, his delirium worsened with strong outbursts, thus treatment continuation was extremely difficult. His family asked that we stop aggressive medication treatment and try only two to three cups of cocoa, which can supplement copper daily.

\section{OUTCOME AND FOLLOW-UP}

Serum copper and ceruloplasmin recovered rapidly, serum ferritin declined and blood cell count recovered after just a few days of drinking cocoa. His delirium also disappeared rapidly from the day after starting cocoa. Moreover, activity of daily life recovered rapidly (figure 1). Because he became cooperative with medical treatment, we used diuretics and BCAA sequentially. Eventually, he could walk on his own and was discharged on the 74th day and was ambulatory.

The blood cells subsequently recovered: $\mathrm{Hb} 14.3 \mathrm{~g} / \mathrm{dL}$, however, Babinski reflexion remained positive 4 months after the start of copper supplementation. He continued abstinence after being discharged from our hospital and has had no relapse after 2 years of follow-up.

\section{DISCUSSION}

This is the first case report clinically, suggesting that excessive alcohol consumption can be a risk factor for copper deficiency.

Copper is an essential element in the body, absorbed from the jejunum to duodenum, ${ }^{10}$ and it spreads throughout the body via the liver. It acts as a coenzyme for many enzymes, and in particular, plays an important role in the bone marrow and nerve system. ${ }^{11}$ Therefore, copper deficiency can result in blood cell abnormalities such as various types of anaemia (microcytic, normocytic, macrocytic anemia) and leucopenia ${ }^{1}$, and neurologic symptoms such as neuropathy, myelopathy, and vision loss ${ }^{2}$. In particular, it is important to differentiate this from vitamin B12 deficiency because the phenotypes are similar. Copper supplementation recovers blood cell abnormalities favourably. ${ }^{3}$ For neurological symptoms, however, the recovery is partial, and it is thought that neurological symptoms will become irreversible if treatment is delayed. ${ }^{12}$. Therefore, it is important to diagnose copper deficiency and start treatment early.

Copper deficiency may be overlooked. Although the exact frequency of copper deficiency is unknown, primary copper deficiency is considered relatively rare as copper is included in most diets. ${ }^{3}$ Typically, clinician awareness is low, ${ }^{13}$ which makes correct diagnosis difficult. Generally, we suspect copper deficiency if the patient has a known risk factor. Known risk factors include special nutritional conditions such as long-term tube feeding ${ }^{4}$ and long-term parenteral nutrition ${ }^{5}$ or gastrointestinal problems such as postgastrectomy ${ }^{6}$ and postobesity surgery ${ }^{7}$ or other conditions, such as zinc intake. ${ }^{8}$ There are several case reports about copper deficiency of unknown cause. ${ }^{9}$ This suggests that clinically there may be other risk factors.

This case clinically suggests that excessive alcohol consumption can be a risk factor for copper deficiency. There are three reasons supporting this. First, the patient did not have any other known risk factors, and he was not a candidate for any other remarkable cause other than excessive alcohol consumption. Moreover, he had no recurrence after abstinence and after the copper supplementation. It was possible that a decreased volume of meals might have affected the onset of copper deficiency, however, this alone could not explain the progression speed of the disease such that the condition emerged after only 3 months of not eating properly. It is most likely that prior to 3 months ago he had small meals. Moreover, he was eating fish and meat, which contain ample amounts of copper. Therefore, we think that it was less likely that he became copper deficient from diet alone. In previous reports, it takes more than a half year to 1 year for copper deficiency to emerge in long-term tube feeding or parenteral nutrition. ${ }^{45}$ Thus, an insufficient intake by itself would not explain the short 3-month course. Second, 
experimental data from rat studies ${ }^{14}$ by Fields et al reported that copper deficiency with organ disorder did not occur in rats fed a copper deficient diet. However, organ disorders such as anaemia occurred in rats fed a copper deficient diet and $20 \%$ ethanol for 6 weeks. Although this was experimental rat data, it suggests that alcohol consumption causes copper deficiency. Third, there is human epidemiological data. ${ }^{15}$ Zhang et al reported that serum copper levels in healthy Chinese volunteers who drank regularly were significantly lower than that who did not have a drinking habit. Although it is unknown whether the organ disorder of copper deficiency occurred in this report, it suggests that drinking alcohol affects human copper metabolism. Based on these supporting studies, this case clinically suggests that alcohol abuse can be a cause of copper deficiency. Unfortunately, the exact mechanism whereby alcohol causes copper deficiency is unknown. From the point of view of rapid disease progression, new mechanisms may be considered, such as copper consumption or excretion promotion rather than a problem with intestinal absorption.

An effective method of copper supplementation is oral administration of cocoa. Although the amount of necessary copper supplementation is not established, it is said to be 2 to $6 \mathrm{mg} /$ day, ${ }^{12}{ }^{16}$ which is several times the required amount of copper, which as an essential dietary micronutrient is $0.9 \mathrm{mg} / \mathrm{day}^{17}$. However, when copper is deficient, absorption efficiency from the intestinal tract increases ${ }^{18}$ if there are no problems with the intestinal tract, and thus an extreme increase may not be necessary. In this case, we chose cocoa as a copper supplement. Cocoa contains a moderate amount of copper and is a convenient beverage. ${ }^{19} 20$ This cocoa contained about $0.2 \mathrm{mg}$ of copper per cup, and as such, he consumed 0.4 to $0.6 \mathrm{mg} /$ day. His symptoms dramatically improved even with this small amount of supplementation.

This case report has some limitations. First, it is difficult to precisely distinguish neurological symptoms including delirium from hepatic encephalopathy and alcohol withdrawal. However, treatment of hepatic encephalopathy or alcohol withdrawal did not improve his symptoms, which instead worsened. Meanwhile, his neurological symptoms such as delirium recovered from the very next day after copper supplementation. From this characteristic course, we presumed that the main pathological condition was copper deficiency. Second, we did not prove that there was a blood cell abnormality due to copper deficiency by bone marrow examination. Therefore, it is difficult to distinguish from blood cell abnormalities due to alcohol toxicity. However, the dramatic progressive increase in reticulocytes in just a few days after copper supplementation by cocoa suggests that copper deficiency was the main cause.

\section{Learning points}

- Copper deficiency should be part of the differential if patients have blood cell abnormalities and neurological symptoms.

- Alcohol abuse can be a risk factor for copper deficiency.

- Cocoa can easily replenish copper requirements.
We experienced a case of copper deficiency due to an excessive habitual alcohol consumption. We encourage clinicians to suspect copper deficiency when patients with an alcohol habit have blood cell abnormalities and neurological symptoms. Further investigation is needed to elucidate the mechanism causing copper deficiency with excessive alcohol consumption.

Contributors Authors' contributions are following: SS, corresponding author wrote the draft. SU, KT and NT revised the article for intellectual content.

Competing interests None declared.

\section{Patient consent Obtained.}

Provenance and peer review Not commissioned; externally peer reviewed.

Open Access This is an Open Access article distributed in accordance with the Creative Commons Attribution Non Commercial (CC BY-NC 4.0) license, which permits others to distribute, remix, adapt, build upon this work non-commercially, and license their derivative works on different terms, provided the original work is properly cited and the use is non-commercial. See: http://creativecommons.org/ licenses/by-nc/4.0/

(C) BMJ Publishing Group Ltd (unless otherwise stated in the text of the article) 2017. All rights reserved. No commercial use is permitted unless otherwise expressly granted.

\section{REFERENCES}

1 Gregg XT, Reddy V, Prchal JT. Copper deficiency masquerading as myelodysplastic syndrome. Blood 2002;100:1493-5.

2 Kumar N, Gross JB, Ahlskog JE. Copper deficiency myelopathy produces a clinical picture like subacute combined degeneration. Neurology 2004;63:33-9.

3 Gabreyes AA, Abbasi HN, Forbes KP, et al. Hypocupremia associated cytopenia and myelopathy: a national retrospective review. Eur J Haematol 2013;90:1-9.

4 Chen CC, Takeshima F, Miyazaki T, et al. Clinicopathological analysis of hematological disorders in tube-fed patients with copper deficiency. Intern Med 2007;46:839-44.

5 Fuhrman MP, Herrmann V, Masidonski P, et al. Pancytopenia after removal of copper from total parenteral nutrition. JPEN J Parenter Enteral Nutr 2000;24:361-6.

6 Imataki O, Ohnishi H, Kitanaka A, et al. Pancytopenia complicated with peripheral neuropathy due to copper deficiency: clinical diagnostic review. Intern Med 2008;47:2063-5

7 Kumar P, Hamza N, Madhok B, et al. Copper deficiency after gastric bypass for morbid obesity: a systematic review. Obes Surg 2016;26:1335-42

8 Sochet $A A$, Jones $A$, Riggs $C D$, et al. A 3-year-old boy with severe anemia and neutropenia. Pediatr Ann 2013;42:15-17.

9 Kumar N. Copper deficiency myelopathy (human swayback). Mayo Clin Proc 2006:81:1371-84

10 Collins JF, Prohaska JR, Knutson MD. Metabolic crossroads of iron and copper. Nutr Rev 2010;68:133-47

11 Stern BR, Solioz M, Krewski D, et al. Copper and human health: biochemistry, genetics, and strategies for modeling dose-response relationships. J Toxicol Environ Health B Crit Rev 2007;10:157-222.

12 Jaiser SR, Winston GP, myelopathy Cdeficiency. J Neurol 2010;257:869-81.

13 Halfdanarson TR, Kumar N, Li CY, et al. Hematological manifestations of copper deficiency: a retrospective review. Eur J Haematol 2008:80:523-31.

14 Fields M, Lewis CG. Alcohol consumption aggravates copper deficiency. Metabolism 1990;39:610-3.

15 Zhang HQ, Li N, Zhang Z, et al. Serum zinc, copper, and zinc/copper in healthy residents of Jinan. Biol Trace Elem Res 2009;131:25-32.

16 Prodan $\mathrm{Cl}$, Bottomley SS, Holland NR, et al. Relapsing hypocupraemic myelopathy requiring high-dose oral copper replacement. J Neurol Neurosurg Psychiatry 2006:77:1092-3.

17 Trumbo P, Yates AA, Schlicker S, et al. Dietary Reference Intakes. J Am Diet Assoc 2001;101:294-301.

18 Turnlund JR, Keyes WR, Peiffer GL, et al. Copper absorption, excretion, and retention by young men consuming low dietary copper determined by using the stable isotope 65Cu. Am J Clin Nutr 1998;67:1219-25.

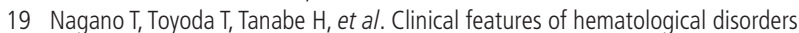
caused by copper deficiency during long-term enteral nutrition. Intern Med 2005:44:554-9.

20 Nishiwaki S, Iwashita M, Goto N, et al. Predominant copper deficiency during prolonged enteral nutrition through a jejunostomy tube compared to that through a gastrostomy tube. Clin Nutr 2011;30:585-9. 
Copyright 2017 BMJ Publishing Group. All rights reserved. For permission to reuse any of this content visit http://group.bmj.com/group/rights-licensing/permissions.

BMJ Case Report Fellows may re-use this article for personal use and teaching without any further permission.

Become a Fellow of BMJ Case Reports today and you can:

- Submit as many cases as you like

- Enjoy fast sympathetic peer review and rapid publication of accepted articles

- Access all the published articles

- Re-use any of the published material for personal use and teaching without further permission

For information on Institutional Fellowships contact consortiasales@bmjgroup.com

Visit casereports.bmj.com for more articles like this and to become a Fellow 